\title{
Improving Rooting of Neem (Azadarachta indica A:Juss) Plant as Responce to Cutting and Auxin Types \\ El-Boraie, E. A.
}

Veget. and Flori. Dept. Fac. Agric, Damietta. Univ, Egypt

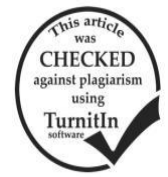

ABSTRACT

Two experimental pots were carried out during the two successive seasons of 2014 and 2015 at the experimental nursery Department fac. of Agric. Damietta Univ. to study the most suitable cuttings types for propagation of neem plant (soft cutting, semi wood and wood cuttings) investigate the effect of auxins treatment Indolbytric acid (IBA1000 ppm) or Naphthalene acetic acid (NAA1000 ppm) plus the control treatment (distilled water) on root formation of neem cuttings. The highest value of rooting percentage, rooting growth, vegetative growth and reducing sugar with soft cuttings of neem plants treated with IBA at $1000 \mathrm{ppm}$ Keywords: Neem soft, semi wood, wood cuttings IBA. NAA.

\section{INTRODUTION}

Neem (Azadirachta indica A.Juss belongs to family Meliaceae; it is an evergreen tree and widely known in South and South East Asia and west Africa.Neem is one of the important multipurpose tree have demonstrated environment, products from all parts of the plant concentrated azadirachtine (Schmutterer, 1990, Gaukar, 2000) and (Thoeming et al, 2006).

Recently neem oil can be used as fuel in diesel engines. The bio diesel production with a high diesel which as economic evaluation (Deepak et al., 2013).Neem can bred for its medicine, fuel wood, pesticides fungicides, nematicides, draught and diseases resistance (Kundu and luukkanen, 2003) and (Palanisamy and Kumar, 1997, 2001). Vegetative propagation of several plants in the mature growth phases reduces the long non flowering juvenile characteristics of most seedling plant vegetative propagation produce plant identical in genotype with the mother plant. Hartmann et al. (1990).Cuttings are the most important methods for the propagation of ornamental shrubs. it's also used widely in commercial green house propagation of many plants . The type of wood and the stage of growth used in making the cuttings, their factors can be very important in rooting of some plants (Hartmann et al., 2011).

Auxins have the greatest effect on root formation in cuttings (keul, 1968). Haissing (1974) postulated that lack of enzymes activities, presents of enzyme inhibitor, lack of substrate phenols, lack of necessary enzymes to synthesis the root inducing auxin-phenols-conjugates and physical separation of enzyme reactants due to cellular compartmentalization.Carbohydrate have been play an important and significant role in growth of adventitious roots (Nanda and Kochhar, 1984).The techniques of vegetative propagation development reduce the variability and productivity. Program of vegetative propagation by selecting elite clones from cuttings are be taken. Propagators usually chosen the source of cuttings, healthy, vigorous, young shoots with viable buds and well matured. Juvenility and maturity of stem cuttings act an important role of rooting. Several types of stem cuttings depending on branch maturity (Hartmann et al., 2011).

The use of plant growth regulators exactly auxins plays an important role in influences the formation of rooting cuttings adventious. IBA and NAA usually recommended to promote adventatious roots in shrubs and trees cuttings (Husen, 2008). The highest root formation could be attributed due to using high humidity by mist propagation it increase number of root and root elongation (Khayyat et al., 2007, Elnaggare and Elnasharty, 2009). Palanisamy and Kumar (1997) reported that cuttings $(25 \mathrm{~cm}$ long, $1.0: 1.5 \mathrm{~cm}$ diameter of neem) were taken from 20 years old trees and treated with (water, IBA, IAA, at 1000, 2000, 3000 pmm IBA induced rooting percentage $(80 \%)$.

Devarnavadagi et al. (2005) studied the effect of auxin IBA, at $1000 \mathrm{ppm}$ for $10 \mathrm{~min}$ recorded high sprouting rooting. Ehiagbonare (2007) reported vegetative propagation studies on some key medicinal plat using $50 \mathrm{ppm}$ IBA showed significant difference in response to the effect of IBA in rooting stem cuttings.

Gehlot et al. (2014) reported vegetative propagation of neem by using mini cutting $250 \mathrm{ppm}$ IBA showed the best results with sand $(80 \%)$ rooting percentage, number of roots, root length, number of leaves.

The main goal of this research was to evaluate influence of cutting and auxin types on neem rooting characters and the reducing suger percentage.

\section{MATERIALS AND METHODS}

\section{Experiment Design:}

The layout of the experiment was in split plot design with three replicates each of which consist of 10 cuttings was done in 2014 and 2015 seasons.Since, the main plot includes the auxin types factor [control (distilled water), 1000mg/l IBA and $1000 \mathrm{mg} / \mathrm{l} \mathrm{NAA]with} 10$ minutes souking for the three types of cutting (soft, semi wood and wood cutting), as they represent the sub main factor. The culture process of the treated cutting were done in mixture of (peat moss: sand: vermiculite) $(1: 1: 1 \mathrm{v} / \mathrm{v})$ and put under mist propagation system ( $5 \mathrm{sec} / 10 \mathrm{~min})$ after 60 days data were recorded

\section{Rooting characters:}

1-Rooting percentage.

3-Root length $(\mathrm{cm})$.

2-Number of roots.

4-Root fresh weight (g).

5-Root dry weight (g)

-Vegitative characters:

1-Number of branches. 2-Number of leaves.

3-Vegetative fresh weight (g). 4-Vegetative dry weight (g).

Reducing sugar \%:-

Reducing sugar percentages was estimated according to method of Krishnaveni et al. (1984). The reducing sugar was determined after three weeks from the beginning of treatment on the base of cuttings.

Statistical analysis

The data obtained were subjected to analysis of variance according to the procedure outlined by Gomez and Gomez (1984). Differences among means were compared by using the least significant differences test (LSD) modified by (Waller and Duncan, 1969). All statistical analysis was performed using the computer program and statistical analysis systems (SAS, 2001).

\section{RESULTS AND DISCUSSION}

\section{Root characters:}

Concerning the effect of auxin treatments and cutting types on rooting percentage, number of roots/cutting and root 
length, data in Table 1 showed that a significant effect in the two seasons. Cuttings soaked in IBA at $1000 \mathrm{mg} / \mathrm{l}$ gave the highest values of rooting percentage (78.9 and $77.8 \%$, resp) and root length (11.3 and $11.4 \mathrm{~cm}$, resp.) whereas the NAA at $1000 \mathrm{mg} / \mathrm{l}$ recorded the highest values of number of roots/cutting (77.0 and 76.0, respectively). On the other hand, control treatment produced the lowest values in this respect. Also, the data illustrated in the same table, showed that cutting types had a significant effect for above root characters. Soft cutting recorded the highest values of rooting $\%$ which were 62.2 and $63.3 \%$ respectively, meanwhile wood cutting increased number of roots/cutting (60.0 and $60.7)$ and produced the longest root length $(7.2$ and $7.6 \mathrm{~cm}$, respectively).

The interaction between auxin treatments and cutting types had significant effect on rooting $\%$ in the two season. It appears that the combination IBA+soft cutting gave the highest value $(93.3 \%)$ in this respect. The combination of NAA at $1000 \mathrm{mg} / \mathrm{l}$ and wood cutting was increased number of roots/cutting. IBA + wood cutting significantly recorded the longest roots $(12.2$ and $12.9 \mathrm{~cm})$ during the two seasons with have significant effects. These results agree with those obtained by (Khayyat et al., 2007, Elnaggare and Elnasharty, 2009), Palanisamy and Kumar (1997) and (Nanda and Kochhar, 1984).

Table 1. Effect of the auxin, cutting types and their interactions on root characters of Neem plant during 2014 and 2015 seasons.

\begin{tabular}{|c|c|c|c|c|c|c|}
\hline \multirow[t]{2}{*}{ Treatments } & \multicolumn{2}{|c|}{$\begin{array}{c}\text { Rooting } \\
\text { percentage }(\%\end{array}$} & \multicolumn{2}{|c|}{$\begin{array}{l}\text { Number of } \\
\text { roots/cutting }\end{array}$} & \multicolumn{2}{|c|}{$\begin{array}{l}\text { Root length } \\
(\mathrm{cm})\end{array}$} \\
\hline & 2014 & 2015 & 2014 & 2015 & 2014 & 2015 \\
\hline \multicolumn{7}{|c|}{ A. Auxin } \\
\hline $\mathrm{mg} / \mathrm{l}$ & 23.3 & 25.6 & 28.6 & 27.7 & 2.9 & 2.9 \\
\hline IBA at $1000 \mathrm{mg} / \mathrm{l}$ & 78.9 & 77.8 & 62.4 & 62.3 & 11.3 & 11.4 \\
\hline NAA at $1000 \mathrm{mg} / \mathrm{l}$ & 61.1 & 60.0 & 77.0 & 76.0 & 5.7 & 5.7 \\
\hline$\underline{\mathrm{LSD}}$ at $5 \%$ & 0.6 & 0.66 & 1.34 & 1.02 & 0.09 & 0.18 \\
\hline \multicolumn{7}{|c|}{ B. Cutting types } \\
\hline Soft cutting & 62.2 & 63.3 & 51.2 & 49.7 & 5.8 & 5.7 \\
\hline Semi-wood cutting & 54.4 & 54.4 & 56.8 & 55.7 & 6.9 & 6.7 \\
\hline Wood cutting & 46.7 & 45.5 & 60.0 & 60.7 & 7.2 & 7.6 \\
\hline LSD at $5 \%$ & 0.5 & 0.57 & 0.5 & 1.1 & 0.09 & 0.11 \\
\hline \multicolumn{7}{|c|}{ C. Interaction (AxB) } \\
\hline Soft cutting & 26.7 & 26.7 & 26.3 & 24.0 & 2.3 & 2.3 \\
\hline $0 \mathrm{mg} / \mathrm{l} \begin{array}{c}\text { Semi-wood } \\
\text { cutting }\end{array}$ & 23.3 & 26.7 & 28.3 & 26.7 & 3.0 & 3.1 \\
\hline Wood cutting & 20.0 & 23.3 & 31.0 & 32.3 & 3.3 & 3.3 \\
\hline \multirow{3}{*}{$\begin{array}{lc}\text { IBA at } & \text { Soft cutting } \\
1000 & \text { Semi-wood } \\
\mathrm{mg} / \mathrm{l} & \text { cutting } \\
& \text { Wood cutting } \\
\end{array}$} & 93.3 & 93.3 & 56.0 & 56.0 & 10.7 & 10.5 \\
\hline & 76.7 & 76.7 & 63.7 & 62.0 & 11.1 & 10.7 \\
\hline & 66.7 & 63.3 & 67.7 & 69.0 & 12.2 & 12.9 \\
\hline \multirow{4}{*}{$\begin{array}{lc}\text { NAA } & \text { Soft cutting } \\
\text { at } & \text { Semi-wood } \\
1000 & \text { cutting } \\
\text { mg/l } & \text { Wood cutting } \\
\end{array}$} & 66.7 & 70.0 & 71.3 & 69.0 & 4.5 & 4.3 \\
\hline & 63.3 & 60.0 & 78.3 & 78.3 & 6.5 & 6.2 \\
\hline & 53.3 & 50.0 & 81.3 & 80.7 & 6.1 & 6.5 \\
\hline & 0.9 & 1.04 & 1.51 & 1.9 & 0.16 & 0.24 \\
\hline
\end{tabular}

Data illustrated in Table 2 showed the means of root fresh and dry weights of Neem plant cuttings as affected by the soaking in auxins, cutting types and their interaction. Data showed that, soakoing cuttings in auxins significantly affected roots fresh and dry weights. The highest values were recorded at NAA which were 0.813 and $0.802 \mathrm{~g}$ for fresh and 0.090 and $0.089 \mathrm{~g}$ for dry weigh, respectively. The same table, cutting types were significantly increased the root fresh and dry weights in 2014 and 2015 seasons. Wood cuttings produced the heaviest root fresh $(0.731$ and $0.718 \mathrm{~g})$ and dry (0.081 and $0.079 \mathrm{~g}$ ) weights during two seasons compared with other treatments. With respect to the interaction between the two factors under this study the data reveal that there are significant effects on root fresh and dry weights. These results agree with those obtained by Hamooh (2004), Deepak et al. (2013) and Gehlot et al. (2015).

Table 2. Effect of the auxin, cutting types and their interactions on root fresh and dry weights of Neem plant during 2014 and 2015 seasons.

\begin{tabular}{|c|c|c|c|c|c|}
\hline \multirow{2}{*}{\multicolumn{2}{|c|}{ Treatments }} & \multicolumn{2}{|c|}{ Root fresh weight (g) } & \multicolumn{2}{|c|}{ Root dry weight (g) } \\
\hline & & 2014 & 2015 & 2014 & 2015 \\
\hline \multicolumn{6}{|c|}{ A. Auxin } \\
\hline \multirow{4}{*}{\multicolumn{2}{|c|}{$\begin{array}{l}0 \mathrm{mg} / \mathrm{l} \\
\mathrm{IBA} \text { at } 1000 \mathrm{mg} / \mathrm{l} \\
\mathrm{NAA} \text { at } 1000 \mathrm{mg} / \mathrm{l} \\
\text { LSD at } 5 \%\end{array}$}} & 0.456 & 0.446 & 0.050 & 0.049 \\
\hline & & 0.777 & 0.747 & 0.086 & 0.083 \\
\hline & & 0.813 & 0.802 & 0.090 & 0.089 \\
\hline & & 0.01 & 0.008 & 0.007 & 0.01 \\
\hline \multicolumn{6}{|c|}{ B. Cutting types } \\
\hline \multirow{4}{*}{\multicolumn{2}{|c|}{$\begin{array}{l}\text { Soft cutting } \\
\text { Semi-wood cutting } \\
\text { Wood cutting } \\
\text { LSD at } 5 \%\end{array}$}} & 0.624 & 0.612 & 0.069 & 0.068 \\
\hline & & 0.690 & 0.664 & 0.076 & 0.074 \\
\hline & & 0.731 & 0.718 & 0.081 & 0.079 \\
\hline & & 0.011 & 0.008 & 0.005 & 0.009 \\
\hline \multicolumn{6}{|c|}{ C. Interaction (AxB) } \\
\hline \multirow{3}{*}{$0 \mathrm{mg} / \mathrm{l}$} & Soft cutting & 0.417 & 0.397 & 0.046 & 0.044 \\
\hline & $\begin{array}{l}\text { Semi-wood } \\
\text { cutting }\end{array}$ & 0.463 & 0.437 & 0.050 & 0.048 \\
\hline & Wood cutting & 0.487 & 0.503 & 0.054 & 0.056 \\
\hline \multirow{3}{*}{$\begin{array}{l}\text { IBA at } \\
1000 \\
\mathrm{mg} / \mathrm{l}\end{array}$} & Soft cutting & 0.710 & 0.690 & 0.079 & 0.077 \\
\hline & $\begin{array}{l}\text { Semi-wood } \\
\text { cutting }\end{array}$ & 0.797 & 0.750 & 0.089 & 0.083 \\
\hline & Wood cutting & 0.823 & 0.800 & 0.091 & 0.089 \\
\hline \multirow{4}{*}{$\begin{array}{l}\mathrm{NAA} \\
\text { at } \\
1000 \\
\mathrm{mg} / \mathrm{l} \\
\end{array}$} & Soft cutting & 0.747 & 0.750 & 0.083 & 0.083 \\
\hline & $\begin{array}{l}\text { Semi-wood } \\
\text { cutting }\end{array}$ & 0.810 & 0.807 & 0.090 & 0.090 \\
\hline & Wood cutting & 0.883 & 0.850 & 0.098 & 0.094 \\
\hline & $5 \%$ & 0.018 & 0.015 & 0.009 & .015 \\
\hline
\end{tabular}

\section{Vegetative characters:}

Data in presented Table (3) showed that treated neem cutting with IBA at $1000 \mathrm{mg} / \mathrm{l}$ significantly increased no. of branches and leaves/cutting which were 3.55 and 3.67 for number of branches and 7.89 and 8.22 for number of leaves during 2014 and 2015 seasons, respectively. Regarding to the cutting types of neem plant, data in the same table revealed that there were significant effects on number of branches and leaves in the two seasons. Since the semi-wood and recorded the highest value in the first season (6.44) compared to wood cutting which was 6.33 . Wood cutting produced high number of leaves/cutting in 2015 season (6.78). There were significant differences in number of branches and leaves/cutting due to the interactions between the two factors under this study. IBA at $1000 \mathrm{mg} / \mathrm{l}+$ wood cutting gave the highest values in this respect through two seasons. These results agree with those obtained by Devarnavadagi et al. (2005) and Ehiagbonare (2007).

Means of vegetative fresh and dry weights were significantly affected by auxin treatments in two seasons (Table 4). Soaking cuttings with IBA produced the highest values of vegetative fresh (7.17 and $7.07 \mathrm{~g})$ and dry (1.79 and $1.78 \mathrm{~g}$ ) weights. Regarding the cutting types, results in same table revealed that there were a significant effect for vegetative fresh and dry weights. Semi-wood or wood cutting gave the heaviest values of vegetative fresh weight significantly differences between them during the two seasons. Wood cutting recorded the highest values of vegetative dry weight during 2014 and 2015 seasons. There is significant effect in interactions between auxin and cutting types over two seasons. Almost, the combination between IBA + semi-wood or wood cutting gave the heaviest fresh and dry weight of vegetative growth. These results are in harmony with Aminah et al. (1997) and Gehlot et al. (2014). 
Table 3. Effect of the auxin, cutting types and their interactions on branches and leaves number/ cutting of Neem plant during 2014 and 2015 seasons.

\begin{tabular}{|c|c|c|c|c|}
\hline \multirow[t]{2}{*}{ Treatments } & \multicolumn{2}{|c|}{$\begin{array}{c}\text { Number of } \\
\text { branches/cutting }\end{array}$} & \multicolumn{2}{|c|}{$\begin{array}{c}\text { Number of } \\
\text { leaves /cutting }\end{array}$} \\
\hline & 2014 & 2015 & 2014 & 2015 \\
\hline \multicolumn{5}{|c|}{ A. Auxin } \\
\hline $0 \mathrm{mg} / \mathrm{l}$ & 1.55 & 1.55 & 3.89 & 4.11 \\
\hline $\mathrm{IBA}$ at $1000 \mathrm{mg} / \mathrm{l}$ & 3.55 & 3.67 & 7.89 & 8.22 \\
\hline $\mathrm{NAA}$ at $1000 \mathrm{mg} / \mathrm{l}$ & 2.67 & 2.55 & 6.55 & 6.22 \\
\hline LSD at $5 \%$ & 0.73 & 0.85 & 0.87 & 1.18 \\
\hline \multicolumn{5}{|c|}{ B. Cutting types } \\
\hline Soft cutting & 2.22 & 2.44 & 5.66 & 5.67 \\
\hline Semi-wood cutting & 2.67 & 2.67 & 6.44 & 6.11 \\
\hline Wood cutting & 2.89 & 2.67 & 6.33 & 6.78 \\
\hline LSD at $5 \%$ & 0.55 & 0.6 & 0.48 & 0.59 \\
\hline \multicolumn{5}{|c|}{ C. Interaction $(\mathrm{AxB})$} \\
\hline Soft cutting & 1.33 & 1.33 & 3.33 & 4.00 \\
\hline Semi-wood cutting & 1.67 & 1.67 & 4.00 & 3.67 \\
\hline Wood cutting & 1.67 & 1.67 & 4.33 & 4.67 \\
\hline Soft cutting & 3.33 & 3.67 & 7.67 & 7.33 \\
\hline Semi-wood cutting & 3.33 & 3.67 & 8.00 & 8.00 \\
\hline Wood cutting & 4.00 & 3.67 & 8.00 & 9.33 \\
\hline NAA at $\quad$ Soft cutting & 2.00 & 2.33 & 5.67 & 5.67 \\
\hline 1000 Semi-wood cutting & 3.00 & 2.67 & 7.33 & 6.67 \\
\hline Wood cutting & 3.00 & 2.67 & 6.67 & 6.33 \\
\hline LSD at $5 \%$ & 1.07 & 1.2 & 1.1 & 1.43 \\
\hline
\end{tabular}

Table 4. Effect of the auxin, cutting types and their interactions on vegetative fresh and dry weights Neem plant during 2014 and 2015 seasons

\begin{tabular}{|c|c|c|c|c|c|}
\hline \multirow{2}{*}{\multicolumn{2}{|c|}{ Treatments }} & \multicolumn{2}{|c|}{$\begin{array}{c}\text { Vegetative fresh } \\
\text { weight (g) }\end{array}$} & \multicolumn{2}{|c|}{$\begin{array}{c}\text { Vegetative dry } \\
\text { weight (g) }\end{array}$} \\
\hline & & 2014 & 2015 & 2014 & 2015 \\
\hline \multicolumn{6}{|c|}{ A. Auxin } \\
\hline $0 \mathrm{mg} / \mathrm{l}$ & & 3.54 & 3.74 & 0.88 & 0.93 \\
\hline IBA at 1 & 000 mg/l & 7.17 & 7.07 & 1.79 & 1.78 \\
\hline NAA at & $1000 \mathrm{mg} / \mathrm{l}$ & 5.96 & 5.76 & 1.49 & 1.39 \\
\hline LSD at 5 & $5 \%$ & 0.1 & 0.38 & 0.041 & 0.02 \\
\hline \multicolumn{6}{|c|}{ B. Cutting types } \\
\hline Soft cutt & ing & 5.05 & 5.15 & 1.26 & 1.28 \\
\hline Semi-wc & ood cutting & 5.86 & 5.55 & 1.47 & 1.34 \\
\hline Wood cl & atting & 5.76 & 5.86 & 1.44 & 1.48 \\
\hline LSD at 5 & $5 \%$ & 0.07 & 0.2 & 0.01 & 0.03 \\
\hline \multicolumn{6}{|c|}{ C. Interaction $(\mathrm{AxB})$} \\
\hline \multirow{3}{*}{$0 \mathrm{mg} / \mathrm{l}$} & Soft cutting & 3.03 & 3.63 & 0.76 & 0.89 \\
\hline & Semi-wood cutting & 3.64 & 3.34 & 0.91 & 0.83 \\
\hline & Wood cutting & 3.94 & 4.24 & 0.99 & 1.06 \\
\hline IBA at & Soft cutting & 6.97 & 6.66 & 1.74 & 1.66 \\
\hline 1000 & Semi-wood cutting & 7.27 & 7.27 & 1.82 & 1.82 \\
\hline $\mathrm{mg} / \mathrm{l}$ & Wood cutting & 7.27 & 7.27 & 1.82 & 1.85 \\
\hline NAA at & Soft cutting & 5.15 & 5.15 & 1.29 & 1.29 \\
\hline 1000 & Semi-wood cutting & 6.66 & 6.06 & 1.67 & 1.38 \\
\hline $\mathrm{mg} / \mathrm{l}$ & Wood cutting & 6.06 & 6.06 & 1.51 & 1.51 \\
\hline \multicolumn{2}{|c|}{ LSD at $5 \%$} & 0.14 & 0.47 & 0.047 & .04 \\
\hline
\end{tabular}

\section{Reducing sugar \%:-}

From data in Table 5, it is obviously noticed that the auxin treatments had highly significant effect on reducing sugar $\%$ of stem base of neem plant during 2014 and 2015 seasons. The cutting treated with IBA at $1000 \mathrm{mg} / \mathrm{l}$ produced the highest reducing sugar content during two seasons (1.77 and $1.78 \%$, respectively). Also, with concerned to cutting types, data in Table 5 show that reducing sugar was significantly affected over all the seasons. Soft cutting markedly reduced highest reducing sugar (1.48 and $1.47 \%$, respectively) compared with other types. Regarding to the interaction between IBA at $1000 \mathrm{mg} / \mathrm{l}$ and soft cutting it gave the highest values of reducing sugar compared with the residue combinations during the two seasons which were 1.82 and $1.81 \%$, respectively.

These results are in agreement with those obtained by Nanda and Kochhar (1984) and Dessalegn (2003) and Howard et al, (1991a,b).

Table 5. Effect of the auxin, cutting types and their interactions on reducing sugar of stem base of Neem plant during 2014 and 2015 seasons

\begin{tabular}{|c|c|c|c|}
\hline \multirow{2}{*}{\multicolumn{2}{|c|}{ Treatments }} & \multicolumn{2}{|c|}{ Reducing sugar (\%) } \\
\hline & & 2014 & 2015 \\
\hline \multicolumn{4}{|c|}{ A. Auxin } \\
\hline \multicolumn{2}{|c|}{$0 \mathrm{mg} / \mathrm{l}$} & 0.93 & 0.92 \\
\hline \multicolumn{2}{|c|}{$\mathrm{IBA}$ at $1000 \mathrm{mg} / \mathrm{l}$} & 1.77 & 1.78 \\
\hline \multicolumn{2}{|c|}{$\mathrm{NAA}$ at $1000 \mathrm{mg} / \mathrm{l}$} & 1.56 & 1.60 \\
\hline \multicolumn{2}{|c|}{$\mathrm{LSD}$ at $5 \%$} & 0.04 & 0.04 \\
\hline \multicolumn{4}{|c|}{ B. Cutting types } \\
\hline & 1.48 & 1.47 \\
\hline & Semi-wood cutting & 1.41 & 1.43 \\
\hline \multicolumn{2}{|c|}{ Wood cutting } & 1.37 & 1.39 \\
\hline \multicolumn{2}{|l|}{ LSD at $5 \%$} & 0.03 & 0.02 \\
\hline \multicolumn{4}{|c|}{ C. Interaction $(\mathrm{AxB})$} \\
\hline \multirow{3}{*}{$0 \mathrm{mg} / \mathrm{l}$} & Soft cutting & 1.01 & 0.99 \\
\hline & Semi-wood cutting & 0.87 & 0.87 \\
\hline & Wood cutting & 0.90 & 0.90 \\
\hline \multirow{3}{*}{$\begin{array}{l}\text { IBA at } 1000 \\
\mathrm{mg} / \mathrm{l}\end{array}$} & Soft cutting & 1.82 & 1.81 \\
\hline & Semi-wood cutting & 1.78 & 1.80 \\
\hline & Wood cutting & 1.72 & 1.74 \\
\hline \multirow{3}{*}{$\begin{array}{l}\text { NAA at } 1000 \\
\mathrm{mg} / \mathrm{l}\end{array}$} & Soft cutting & 1.60 & 1.61 \\
\hline & Semi-wood cutting & 1.59 & 1.63 \\
\hline & Wood cutting & 1.50 & 1.55 \\
\hline \multicolumn{2}{|l|}{ LSD at $5 \%$} & 0.07 & 0.05 \\
\hline
\end{tabular}

\section{Discussion:-}

Vegetative propagation by cuttings was the most important methods for propagation of ornamental, fruit and woody trees by using auxins (IBA, NAA) which increase rooting percentage under mist propagation condition system and accelerated root percentage and enhanced root characters. This data was in agreement with Hartmann et al. (2011), and highly vegetative characters (No. of branches, No. of leaves, fresh weight, and dry weight). These results are in harmony with Aminah et al. (1997) and Gehlot et al. (2014).

The use of plant growth regulators exactly auxins plays an important role in influences the formation of rooting cuttings adventious. IBA and NAA usually recommended to promote adventatious roots in shrubs and trees cuttings (Husen, 2008).

Carbohydrates especially reducing sugar accelerate root initiation and enhanced rooting capacity, the carbohydrates and hormones content were found to be related to the type of cuttings. These results are in agree with those obtained by Nanda and Kochhar (1984) and Dessalegn (2003).

Using IBA and NAA $(1000 \mathrm{mg} / \mathrm{l})$ were increased the highest value of rooting percentage, root characters due to increased reducing sugar by using auxins and cell division in the rooting zone and accelerating rooting cuttings formation (Husen, 2008).

\section{CONCLUSION}

This study show that soft cuttings of neem plant treated wih IBA $1000 \mathrm{mg} / \mathrm{l}$ gave the highest value of rooting percentage, root characters, and vegetative growth characters. 


\section{REFERENCES}

Aminah, H.; J. M. Dick and J. Grace (1997). Rooting of Shorea leprosula stem cuttings decreases with increasing leaf area. Forest Ecology and Management, Amsterdam, 91(2-3):247-254.

Deepak, T.; D. D. S. Aiyta and Y. P. Mathur (2013). Production and characterization of neem oil methy ester. Intern. J. of Engin. Res., 2(5):1896-1903.

Dessalegn, Yigzaw, Reddy, Y.N.(2003): Effects of different concentrations of auxins on rooting and root characters of air and ground layers of jojoba(Simmondsia Chinensis) (Link.) (C.K.Schneider): SINET: Ethiopian Journal of Science, Volume 26, Number 2, December 2003, pp. 155-159(5).

Devarnavadagi, S. B.; A. S. Sajjan and S. Y. Wali (2005). Effect of growth regulator on induction of adventitious rooting in stem cutting of neem. Karnataka J. of Agric. Sci., 18(1): 210-211.

Ehiagbonare, J. E. (2007). Vegetative propagation of some key malaria medicinal plants in Nigeria. Scientific Res. and Essay, 2(2):37-39.

El-Naggar, A. H. and A. B. El-Nasharty (2009). Effects of growing media and mineral fertilization on growth, flowering, bulb productivity and chemical constituents of Hippeastrum vittatum, Herb. American-Eurasian J. of Agric. \& Environ. Sci., 6(3):360-371.

Gahukar, R.T. (2000). Use of neem products/pesticides in cotton pest management. Intern. J. of Pest Manag., 46(2):149-160.

Gehlot, A.; S. Arya and I. Arya (2014). Vegetative propagation of Azadirachta indica A. Juss (neem) through cuttings: a review. Nativa Sinop, 2(4): 239-246.

Gehlot, A.; S. Arya and I. Arya (2015). Influence of cutting diameter, auxin and rooting substrate on adventitious rooting from hardwood cutting of Azadirachta indica A. Juss (neem). Adv. In Fores. Sci., 2(3):49-61.

Gomez, K. A. and A. A. Gomez (1984). Statistical Procedures for Agricultural Research. $2^{\text {nd }}$ Ed. John Wally \& Sons

Haissig, B. E. (1974). Activity of some glycolytic and pentose phosphate pathway enzymes during the development of adventitious roots. Physiologia Plantarum, 55(3):261- 272.

Hamooh, B. T. (2004). Cutting types and IBA concentration in relation to rooting of stem hardwood cuttings of fig tree (Ficus cariaca L.). Annals Agric. Sci. Ain Shams Univ., 49(2): 661-669.

Hartmann, H. T and D. E. Kester and davies F. T. (1990):Plant Propagatiin Principles and Practices Print USA New Jersey 199-304.
Hartmann, H. T and D. E. Kester and davies F. T. (2011): Plant Propagatiin Principles and Practices. $8^{\text {th }}$ Education.New York:Prenntice-Hall. 915p.

Husen A (2008) Clonal Propagation of Dalbergia sissoo Roxb. and associated metabolic changes during adventitious root primordium development. New Forests, 36(1):1327. Doi: 10.1007Ls 11056-007-9079-y.

Howard, B.H. and M. S. Ridout (1991a). Rooting potential in plum hardwood cuttings: I. relationship with shoot diameter. J. of Hort. Sci., 66(6):673-680.

Howard, B. H. and M. S. Ridout (1991b). Rooting potential in plum hardwood cuttings: II. relationships between shoot variables and rooting in cuttings from different sources. J. of Hort. Sci., 66(6):681-687.

Khayyat, M.; F. Nazari and H. Salehi (2007). Effects of different pot mixtures on Pothos (Epipremnun aureum Lindl. And Andre 'Golden Pothos') growth and development. American-Eurasian J. of Agric. and Environ. Sci., 2(4):341-348.

Keul, W .R.(1968): Inereased Root Initiation In Pinato Been Hypocotyls With 2,4 Dinitrophennol Plants Phys $.34(3): 439-41$.

Kundu, S. K. and O. Luukkanen (2003). Genetic diversity and breeding strategies of the neem (Azadirachta indica). In: XII World Forestry Congress, Quebec City, Canada.

Krishnaveni, S. T. Balasubramanian and S. Sadasivam (1984). Technical Note: Sugar Distribution in Sweet Stalk Sorghum. Food Chemistry 15(3): 229-232.

Nanda and Kochhar (1984): Vegetative Propagation of Plants. Kalyyani Publishers New Delhi 234 P.

Palanisamy, K. and P. Kumar (1997). Effect of position, size of cuttings and environmental factors on adventitious rooting in neem (Azadirachta indica A. Juss). Forest Ecology and Manag., Amsterdam, 98(3): 277-280.

Palanisamy, K. and P. Kumar (2001). Vegetative propagation and genetic improvement of neem. Indian Forester, 127(3):347-350.

SAS Institute Inc. (2001). The SAS System for Windiows. Release 6.12, SAS Institute Inc., Cary, NC, USA.

Schmutterer H (1990) propreties and potential of natural pesticides from tehe neem tree, Azadirachta indica. Annual Reviw of Entomology, 35: 271-297. Dol:10.1146Lannurev.en.35.010190.001415.

Thoeming, G.; G. Draeger and H. M. Poehling (2006). Soil application of azadirachtin and 3-tigloyl-azadirachtol to control western flower thrips, Frankliniella occidentalis (Thysanoptera: Thripidae): translocation and persistence in bean plants. Pest Management Sci., 62(8): 759-767.

Waller, R.A. and D.P. Duncan (1969). A bays rule for symmetric multiple comparison problem. Amer. Stat. Assoc. J. December: 1485- 1503.

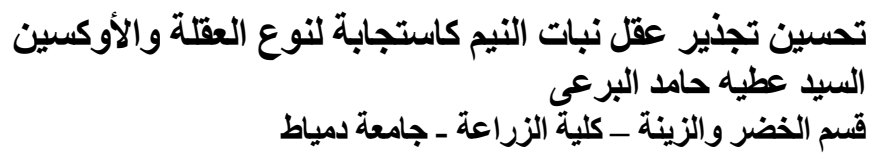

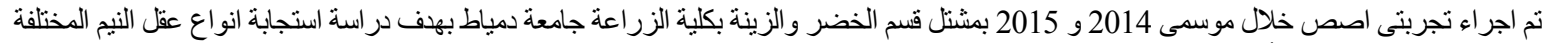

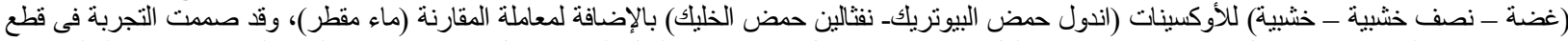

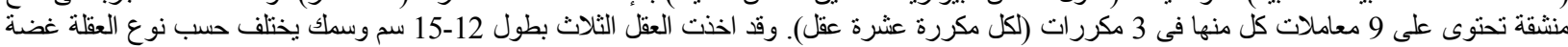

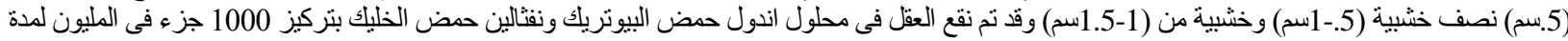

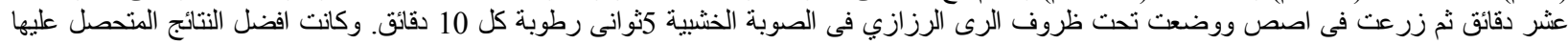

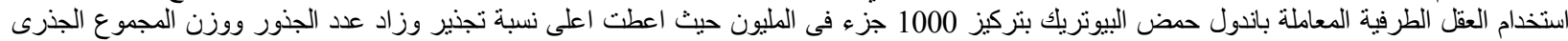

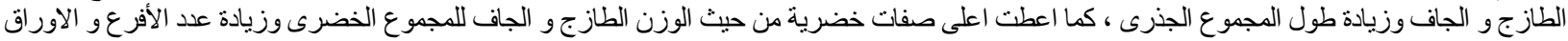

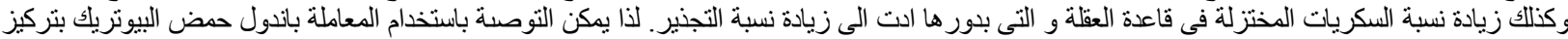

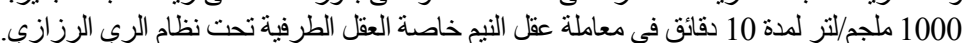

